IRA-International Journal of Applied Sciences ISSN 2455-4499; Vol.03, Issue 03 (2016)

\title{
Process of Oogenesis in Proechinocephalus Egreti (A Digenetic Trematode) Shrivastava, 1960
}

\section{Dr. Rajani Gautam}

Department of Zoology, Career College, Bhopal (M.P.), India.

DOI: http://dx.doi.org/10.21013/jas.v3.n3.p19

\section{How to cite this paper:}

Gautam, R. (2016). Process of Oogenesis in Proechinocephalus Egreti (A Digenetic Trematode) Shrivastava, 1960. IRA-International Journal of Applied Sciences (ISSN 2455-4499), 3(3). doi:http://dx.doi.org/10.21013/jas.v3.n3.p19

(C) Institute of Research Advances

\section{(cc) EY-NC}

This works is licensed under a Creative Commons Attribution-Non Commercial 4.0 International License subject to proper citation to the publication source of the work.

Disclaimer: The scholarly papers as reviewed and published by the Institute of Research Advances (IRA) are the views and opinions of their respective authors and are not the views or opinions of the IRA. The IRA disclaims of any harm or loss caused due to the published content to any party. 


\section{ABSTRACT}

Present paper deals with the study of process of oogenesis of a digenetic trematode Proechinocephalus egreti (a digenetic trematode) of the family Echinostomatidae was collected from the intestine of an Indian cattle egret, Bubulcus ibis coromandus. A few of parasites were flattened on a clean slide under the slight pressure of a cover glass \& fixed in Alcoholic Bouin,s fluid for 12 hours. Stains like Gover's Carmine, Mayer's Para carmine \& Haemalum were used for the preparation of whole mounts for identification \& the study of female reproductive organs \& the process of oogenesis in Proechinocephalus egreti.

Keywords: Proechinocephalus egreti, trematode, oogenesis.

\section{Introduction}

The Digenea, a subclass of the trematodes is composed of a group of parasitic worms whose relationships to one another are not yet certain. Much of the uncertainity may be attributed to the fact that nearly all the major and minor group have been estabilished on the basis of gross morphological characters in the adult. The complicated life histroy of these worm seem to be make it necessary to consider other characters, such as larval and cytological as well as, in attempting to show relationships with in the group (Grady Britt, 1947).

In this group, the germ cells are very small \& they do not stain easily. The Cytoplasmic boundaries of these cells are not clearly visible. The later stages of oogenesis occur after shell formation \& the oocyte is surrounded by the vitelline cells which make the cytological studies more difficult. The survey of available literature reveals that the cytological history of the trematodes starts when Gold Schmidt (1902) described the process of oogenesis in Polystomum integerimum. Henneguy (1902) described oogenesis, maturation \& fertilization in Fasciola hepatica (Distomum hepaticum) \& reported the formation of ectolecithal eggs in this specie. In certain groups of digenetic trematodes the cytomorphological variations in the cytoplasm of the oocytes have been reported by Hanumantha et.al. (1966)

Janicki (1903) studied the certain stages of oogenesis \& cleavages in the eggs of Gyrodactylus elegans. Kathariner (1904) studied oogenesis, fertilization \& cleavage in the same species.

Gille (1914) studied the gametogenesis, fertilization \& cleavage in Gyreodactylus elegans.He reported that the oocytes are accompanied by one or more nutritive cells when they pass from the ootype to the uterus. Cable (1931) gave the review of gametogenesis $\&$ fertilization in trematodes during his description of the germ cell cycle in Cryptocotyle lingua.

The embryologists of the world engaged in the studies of the germ cell cycles in trematodes during the early period. Steenstrup (1842) first outlined the theory of alternation of generation of digenetic trematodes; the method of reproduction in germinal sacs in the intermediate has been a subject of controversy. Grobben (1882) reported the hypothesis that the alternation of generation of digenetic trematodes is a heterogeny \& that the reproductive cells in the germinal cells are true parthenogenetic ova. Later several workers described \& figured the formation of polar bodies by these reproductive cells \& considered that they are produced in definite ovaries or in the walls of germinal sacs. 


\section{Material \& Methods}

Proechinocephalus egreti Srivastava, 1960 (Fig 1)of the family Echinostomatidae Poche, 1926 was collected from the intestine of an Indian cattle egret, Bubulcus ibis coromandus. A few of parasites were flattened on a clean slide under the slight pressure of a cover glass \& fixed in Alcoholic Bouin,s fluid for 12 hours. Stains like Gover,s Carmine, Mayer's Para carmine \& Haemalum were used for the preparation of whole mounts for identification $\&$ the study of reproductive organs.

The smears were prepared from the living material by puncturing the ovary with two fine steel needles under the stereoscopic binocular microscope. The semi fluid contents were allowed to spread over the clean slide \& then the slide is inverted over the fixative without losing much time. After fixation with sublimate acetic the material is washed for 20-24 hours in running water. It is further treated with iodine in $70 \%$ alcohol to assure complete removal of the mercury. Now the blocks were prepared \& sections were cut from 6-10 microns in thickness.

Observations of both living \& fixed material were made with Meopta \& Carlzeis Zena binocular research microscope. Photomicrographs were made with the help of Meopta attachment camera. The films were developed in the fine grain developer (Eastman formula D-11) for 3-5 minutes.

\section{Results and Discussion}

\section{Structure Of Ovary \& Process Of Oogenesis In P.egreti}

The ovary is spherical, intercaecal, pretesticular, sub median\& lying closely to the right caecum, at a distance of $0.918 \mathrm{~mm}$. behind the acetabulum. It is more or less rounded, with entire margin, smaller in size than the testes \& measures $0.98 \mathrm{~mm}$. x 0.35 in size(Fig 2 ). The oviduct arising from the posterior end of the ovary runs towards the median line for a short distance to join the ootype, which is surrounded by a large mass of cells of shell gland. The receptabulum seminis seems to be absent (Gautam, 1991).

The vitelline follicles, small \& close together, occupy the lateral margins of the body extending from the anterior border of the acetabulum to the posterior end. They overlap the intestinal caeca in the testicular region \& practically meet behind the testes. The vitelline follicles are pear shaped $\&$ do not overlap the ovary $\&$ the shell gland mass. The two transverse vitelline ducts, one from each side, meet together to form a yolk reservoir in front of the testes. A short duct arises from it running anteriorly to open at the ootype (Fig 3).

The uterus is thin walled arising from the ootype. It makes a few intercaecal loops between the acetabulum \& the genital field before terminating in a short \& slender metraterm which proceed forwards along the right side of the acetabulum to open at the genital pore. The ova, filling in the uterus, are numerous \& bright yellow in color \& measures $0.085 \mathrm{~mm} . \mathrm{x} 0.051 \mathrm{~mm}$. in size.

\section{Oogenesis}

The oogonia lie in the peripheral region of the ovary \& the developing oocytes are located in the central portion of the ovary (Fig 3).The oogonia possesses little cytoplasm $\&$ a prominent nucleus containing one nucleolus. The nucleolus is not very prominent in this species. The oogonium measures 4 -6 microns \& nucleus measures 2-4 microns in diameter. Most of these cells are in resting stages. They multiply mitotically \& give rise to the oocytes (Fig 4). The primary oocyte grows in size. Young oocytes measure 6-8 microns \& its nucleus measures 3-5 microns in diameter. The nucleus of young primary oocyte enters the prophase stage of first maturation division. It extends up to pachytene 
stage \& then enters a passive condition during which period the growth of the oocyte takes place.

During the growth phase of the oocyte the nucleolus is prominent \& active. It is spherical in shape \& periodically migrates towards the nuclear wall. Fully developed oocytes measures 8-10 microns in diameter. The nucleus measures 4-6 microns \&the nucleolus measures 1-2 microns in diameter. The cytoplasm of fully grown oocyte is finely granular. The granules are stained well in Haematoxylin. They are pyronine in nature.

The fully grown oocyte passes through the oviduct one after the other \& reaches the oocyte where egg shell formation takes place. The penetration of the sperm in the oocyte leads to the initiation of the maturation division. The stages of fertilization have not been taken into consideration during this work, only attention was given to the study of the pre-fertilization stages.

The sequence of stages in the oogenesis of P.egreti is essentially similar to that of the other forms described in the digenetic trematodes .The maturation of the oocyte begins in the ovary \& it is completed in the proximal part of the uterus after the penetration of sperm into the oocyte whish is relevant to the study of Gresson (1964).

Mostly the oogonia lie in the peripheral region \& oocytes are present in the central part of the ovary. The oogonia has little cytoplasm \& one or two nuclei. In the young primary oocytes the leptotene \& zygotene stages are found \& at the set of pachytene stage the oocyte nucleus passes through the diffuse condition. This is also called as extended prophase stage of the first maturation division of the oocyte. Further meiotic activities are initiated only after the penetration of sperm. During this extended prophase stages the oocytes grow in size \& the cytoplasm gets filled up with the nutrient matter.

In digenetic trematodes almost all the growing oocytes possess one or more prominent nucleoli Anderson (1935). They become much active during the growth phase of the oocyte. The fully grown oocytes are found crowded in the vicinity of the oviduct. They enter the oviduct in a single row Burton (1960). Shell formation over the oocyte takes place when it passes through the ootype Burt(1986). The penetration of the sperm in the cytoplasm of the oocyte takes place somewhere in the oviduct or the proximal part of the uterus \& initiates the first maturation division ( Fig 5,6).

\section{REFERENCES}

1. Cable, R. M. 1931. Studies on the germ cell cycle of Cryptocotyle lingua Creplin I. Gametogenesis in the adult .Quart.J.Micr.Sci.74:563-589

2. Gille, K. 1914. Untersuchugen uber die Eireifung,Befruchtung Und Zellteilung Von Gyrodactylus elegans. V.Nordmann.Arch.F.Zellf.12:415-456.

3. Gold schmidt R. 1902. Untersuchugen uber die Eireifung, Befruchtung \& Zellteilung bei Polystomum integerimum Zeit.Wiss-Zool.71:3 97-444.

4. Gresson, R. A. R. (1964) Oogenesis in the hermaphroditic Digenea (Trematoda).Parasite.54:409-412.

5. Gautam, R. 1991. Studies on Reproductive organs, Gametogenesis \& Chromosome numbers of certain Platy helminthes Ph. D. Thesis (1991) A.P.S. Univ. Rewa

6. Hanumantha Rao Madhvi R. 1966. Characterization of oocytes in digenetic trematodes.J.Anim.Morph.Physiol, 13:1-2:201-203.

7. Henneguy, L. F. 1902. Sur La formation de I. Oeuf, la maturation et la Fecondation de I.Oocyte chez le Distomum hepaticum.Pairs,C.R.Acad.,Sci.134:1235-1238 
8. Kathariner, L. 1904. Uber Entwicklung von Gyrodactylus elegans V. . Zool.Jahrb.F.Wiesmann. 7:519-550.

9. Anderson, M. G. 1935. Gametogenesis in the primary generation of a digenetic trematode, Proterometra marcostoma Horsfall,1933 Trans.Amer.soc.54:271-297.

10. Burton, P. R. 1960.Gametogenesis \&Fertilization in frog lung fluke Haematolaechus medioplexus staford (T: plagiorchiidae) J.Morph.107 (1):93-122

11. Burt, M. P. B 1986. Early morphogenesis in the Platy helminthes with special reference to egg development of cestode larvae In: Howell MJ (ed) Parasitology -quo vadit? Australian Academy of Science Camberra, pp 241-253.

12. Grady Britt, H. 1947. Chromosomes of Digenetic Trematodes. The American Naturalist Vol. 81( 99): 276-296.

13. Janicki, C. V. 1903. Beziehungen zwischen chromatin and nucleolen wahrend der Furchung des Eies von Gyrodactylus elegans von Nordm. Zool. Anz., Bd.26.

14. Steenstrup , 1842. Parasitological Reviews Germinal Development in the Sporocysts and Rediae of the Digenetic Trematodes.p-185.

15. Grobben ,1882. Parasitological Reviews Germinal Development in the Sporocysts and Rediae of the Digenetic Trematodes. p-185

16. Srivastava, P. S. 1960. The Fauna of India And The Adjacent Countries Published under the patronage of the Government of India Platyhelminthes. Vol. I Trematoda.P-95.

17. Poche, 1926: Three new' trematodes of the family Echinostomatidae. Indian J. Helminth., 15 (2): 127-137. 
(Figures \& Tables)

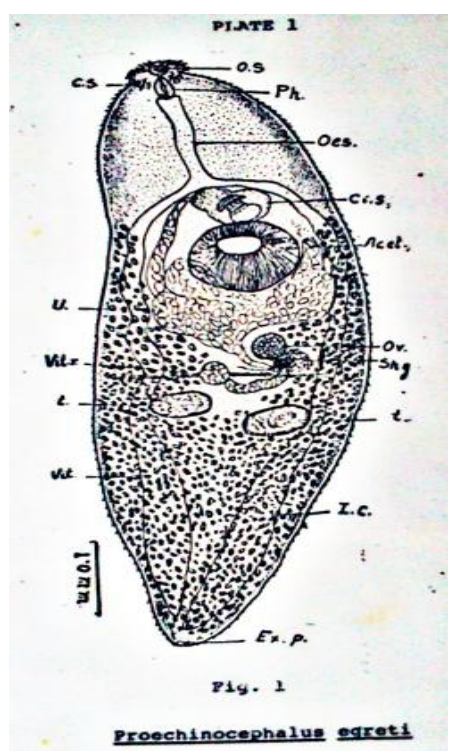

Fig-1 Proechinocephalus egreti ( Camera Lucida sketch)

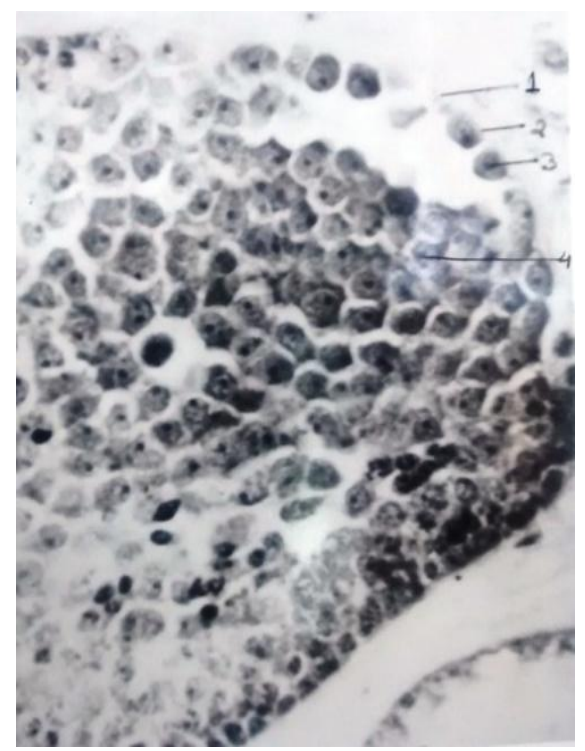

Fig-2 : T.S .of Ovary of P.egreti

1.Wall of fibrous connective tissue

2.Nucleus in fibrous sheath

3.Oogonia in interphase

4.Nucleus in the developing oocyte 


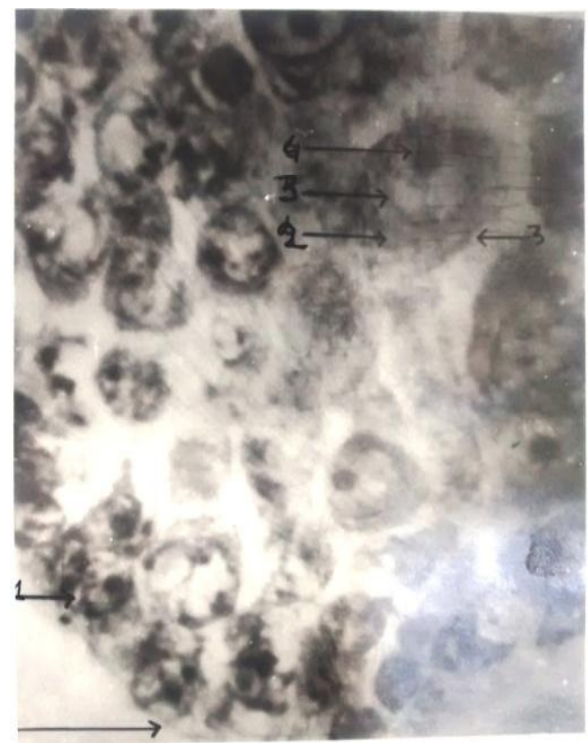

Fig-3 : Portion of T.S.Ovary (Magnified) Bouin's \&Iron Haematoxylin 1 - Wall of fibrous connective tissue

2-Oocyte

3-Nucleus

4-Single prominent nucleolus(Methyl green pyronine).

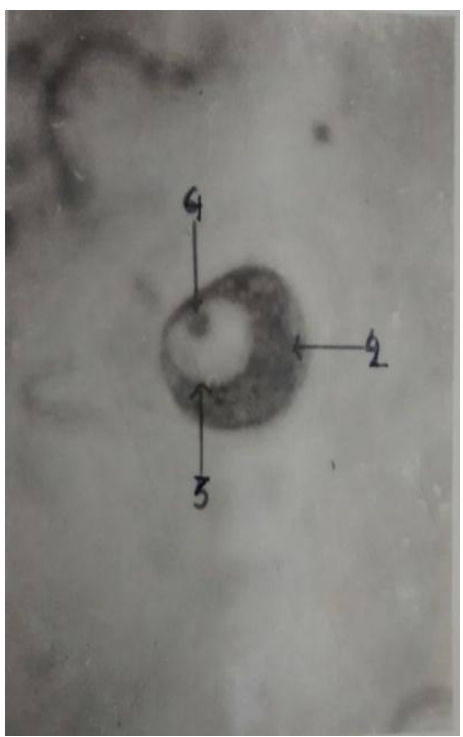

Fig-4: Mature oocyte

2.Oocyte

3.Nucleus

4. Single prominent nucleolus

(Methyl green pyronine) 


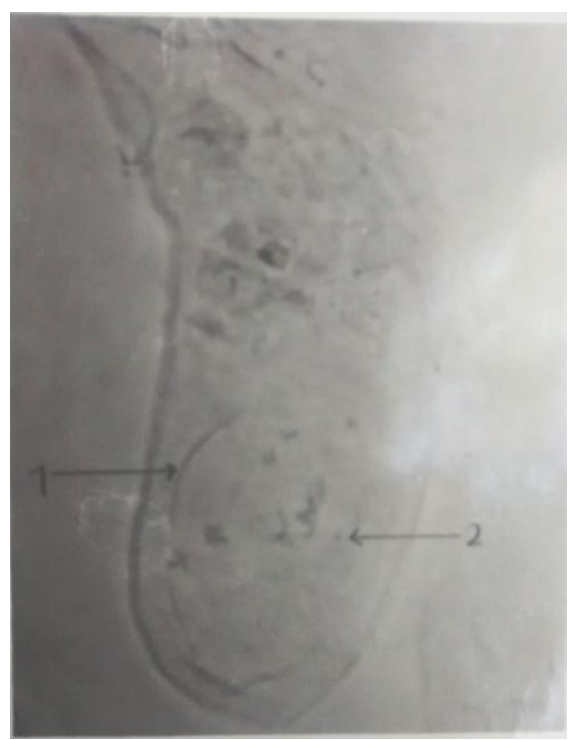

Fig-5

1.Sperm inside the cytoplasm in ovary 2. Eggs

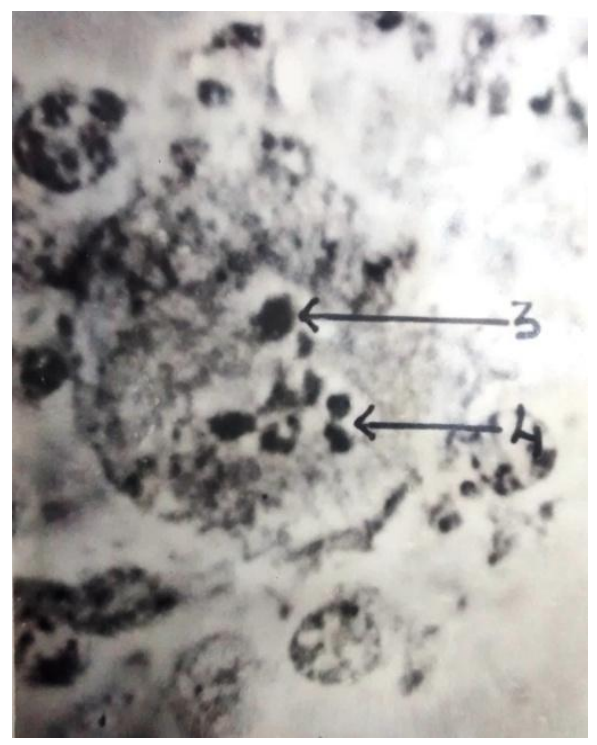

Fig-6: Eggs

3.Sperm Chromosome inside the egg 4.Chromosomes 